\title{
A crise da crítica
}

\author{
The crises of criticism
}

\author{
Larissa Drigo Agostinho \\ Universidade de Paris IV-Sorbonne - Paris - França
}

\begin{abstract}
Resumo: Diante da enorme presença dos diagnósticos contemporâneos sobre o fim da arte e a respeito de uma falência da crítica, procuramos nos interrogar sobre esta questão, traçando uma analogia entre o momento que vive a crítica literária brasileira e a poesia contemporânea em paralelo com a situação da crítica francesa estruturalista e da crítica francesa contemporânea. Procuramos demonstrar que o estado atual de crise que vive o Brasil é análogo ao que ocorre na França, e esta crise tem uma origem comum: o romantismo. Este artigo termina com uma demonstração de como a poesia de Mallarmé pode fornecer um modelo de crítica que nos permitiria sair deste estado de crise.
\end{abstract}

Palavras-chave: Modernidade; Crítica; Poesia lírica

\begin{abstract}
Given the huge presence of contemporary diagnoses about the end of art or a critical failure, we ask ourselves about this question by drawing an analogy between the moment that lives the actual Brazilian literary criticism and are contemporary poetry in parallelism with the situation of French structuralism and the contemporary French criticism. We intend to demonstrate that the current state of crisis affecting Brazil is analogous to what occurs in France, and this crisis has a common origin: the romanticism. This article ends showing how the poetry of Mallarmé tried to find a way out of the crisis he lived due to romanticism and exploring the ideas it contains about criticism.
\end{abstract}

Keywords: Modernity; Criticism; Lyrical poetry

\section{Estruturalismo e marxismo, o prelúdio da crise}

Em 1894, em Oxford, Mallarmé anunciava uma crise na literatura, uma crise no verso. Em 1970, sem o mesmo tom irônico do poeta, Paul de Man, em ensaio intitulado Criticism and Crisis, anunciava uma crise na crítica. Esta crise parece ainda vigorar, mas por razões diferentes. No período em que De Man escreveu esse ensaio, o que lhe parecia um sintomático sinal de crise era a urgência com que várias disciplinas no interior das ciências humanas disputavam a sua liderança, uma corrida provocada pela publicação de Tristes tropiques, que estabeleceu definitivamente o estruturalismo na França. Hoje, o sintoma da crise parece ser o vazio deixado pela ausência desta urgência, pela ausência de um "projeto geral" para as ciências humanas.

Para o crítico, uma crise, como a "Crise de verso" de Mallarmé, ocorre quando há uma separação entre o que, em literatura, é conforme a intenção original e o que irremediavelmente acabou escapando desta fonte. Assim, a questão que deveríamos colocar para a crítica é a seguinte: Estaria a crítica examinando a si mesma até o ponto de refletir sobre sua própria origem? Ou estaria ela se perguntando se a crítica é realmente necessária?

Mas o que significa perguntar se a crítica é suficientemente crítica consigo mesma? Criticar significa, para De Man, julgar, estabelecer se uma obra se adequa a um padrão, se uma obra é boa ou má. No fundo, sabemos que todo julgamento crítico é essencialmente um julgamento de valor. Assim, a crítica e a crise se confundem e, para De Man, poderíamos dizer que são a mesma coisa. A crítica só existe em momentos de crise, em momentos em que precisamos decidir e pensar o que significa escrever, em momentos em que precisamos colocar a literatura em questão. Para o crítico, a crítica continental de seus dias, da década de 70 , poderia assim ser chamada de crítica verdadeira, pois estaria se interrogando sob o que de fato significa o ato de escrever. 
A primeira questão da crítica estruturalista diz respeito à relação entre a literatura e a linguagem não literária, a língua comum, do dia a dia. O principal objetivo da crítica estruturalista é mostrar que a literatura não é uma "linguagem privilegiada". Um dos grandes exemplos desta estratégia está na crítica estruturalista ao termo "romântico". Este exemplo também é interessante, pois demonstra a chave histórica na qual a crítica estruturalista funciona. A descrença na ideia de que na linguagem poética, signo e significado coincidem, ou ao menos se encontram numa relação de harmonia chamada beleza, é conhecida como desilusão romântica. A unidade da aparência (signo) e da ideia (significado) se encarna no mito recorrente no romantismo da "bela alma". A imaginação romântica encarna esta figura, ora feminina, ora masculina ou hermafrodita, e parece insinuar que ela existe de fato, como sujeito empírico, como é o caso, por exemplo, da Julie de Rousseau ou da bela alma como ela aparece na Fenomenologia do Espirito, ou no Wilhelm Meister, de Goethe. Poderíamos inclusive, segundo De Man, pensarmos no desenvolvimento posterior da literatura, no século XIX e XX, como um prolongamento deste esquema de desmistificação crítica, sobretudo no realismo: o tratamento que Flaubert confere ao quixotismo, Stendhal e a ironização da figura rousseauísta, ou Proust e o tratamento que este confere a figura do artista. Isto levaria a elaboração de um esquema histórico de superação das ilusões românticas que culminaria numa nova forma de lucidez.

Este tipo de crítica ao romantismo que se configura como uma crítica da desmistificação ou do desvelamento não esta apenas presente no estruturalismo, mas também no marxismo. Para Foucault (1997, p. 13), a crítica marxista, posterior a Marx evidentemente, realiza uma operação de naturalização do símbolo, acreditando que "há símbolos que existem primariamente". Estes símbolos são sempre os mesmos, na verdade trata-se de uma determinada configuração social e histórica que cabe ao crítico marxista desvelar por trás do texto literário, como seu suporte imanente, como a infraestrutura que determina sempre em linha reta e de maneira unívoca uma superestrutura.

Em "A sereia desmistificada", Bento Prado Jr. faz uma crítica deste modelo de crítica marxista tomando como exemplo o trabalho do crítico Roberto Schwarz. Segundo o filósofo, a crítica de Schwarz não é interpretativa, ela recusa a pluralidade de leituras, fruto das deficiências da razão e do conhecimento crítico "e, monista, tenta capturá-la na revolução que faz girar em torno de um único eixo vertical. Mas como devolver a linguagem delirante da leitura à austeridade do sentido único? Para fazê-lo, é necessário devolver a obra à sua situação". (PRADO JR, 2000, p. 208). E por situação Schwarz entende a totalidade das estruturas sociais.

Sua crítica é monista porque a economia é utilizada para reduzir e restringir o campo da significação, ou para determinar toda significação possível. A crítica é compreendida como adequação entre a fala literária e o mundo, onde o mundo é a experiência do próprio crítico que julga a mitologia do autor sobre o "fundo da razão e da experiência universais". O que a obra não diz é fruto de sua impotência, de sua finitude e aponta para a "omnipotência do discurso crítico, capaz de dizer tudo."

Paulo Arantes (apud PRADO JR, 2000, p. 283-284) rebate esta crítica de Prado Jr. alegando que "seria um despropósito" pensar que o crítico substitui seu discurso pela obra, pois esta é "formalização, e por isso requer o crítico, pois malgrado seu poder de apresentação e síntese a ela não cabe julgar." Se perguntássemos ao autor o que a arte formaliza, a reposta é conhecida, as estruturas sociais. Assim como à literatura não cabe julgar sua adequação ao socialmente e economicamente determinado, ela precisa do crítico literário, único capaz de julgar e evidenciar, de desvelar este processo de formalização. $\mathrm{O}$ que evidentemente reduz o horizonte crítico da própria obra de arte. Trata-se de uma ideia de crítica que se sustenta numa desconfiança, numa suspeita com relação à linguagem, de que ela diz sempre algo além, de que há uma profundidade na obra, uma verdade que se esconde por trás da obra literária e que só o crítico é capaz de mostrar. Como afirma Prado Jr: "Racionalista, ele vê antes de mais nada na linguagem o seu poder de engodo: a linguagem, em seu movimento espontâneo e em seu marulho, adormece a reflexão e a crítica e faz passar, sub-reptícia e clandestinamente, teses inaceitáveis que ofendem a Razão" (PRADO JR, 2000, p. 211).

Assim, se a crítica marxista desvela a economia que determina a obra como a crítica estruturalista encontra na constituição da linguagem a explicação para a obra: “A economia é para Roberto Schwarz o que é a linguística para Roland Barthes: descrição das estruturas que, em última instância, definem o campo de toda significação possível" (PRADO JR, 2000, p. 210).

\section{A crise e suas origens}

Se por um lado, a literatura precisa da indústria cultural, pois se define justamente a partir do distanciamento para com esta, negando absolutamente seus valores, esta oposição entre a literatura e a sociedade burguesa não é suficiente para explicar o modo como a literatura se configura neste fim do século XIX.

Reduzi-la a um estado de crise, de desencantamento do mundo provocado por sucessivos fracassos políticos, poderia fazer da literatura uma denúncia, uma crítica, mas 
uma crítica que se configuraria como mistificação, não como desmistificadora, pois, se por um lado ela procuraria demonstrar o caráter ilusório das ilusões românticas, por outro lado, a instauração na crise mantém a literatura num não lugar, sempre a margem da sociedade, impotente e incapaz de ultrapassar este estado perpétuo de crise. Isto reduziria a literatura a uma afirmação única.

É o que faz Marcos Siscar, em Poesia e Crise, ao afirmar que a crise mallarmeana de 1866, a crise do Nada, não é uma passagem da qual resultaria uma superação, pois não há um além da crise: "trata-se, em vez disso, de uma passagem para a crise, para uma situação em grande parte dilemática, ou seja, uma situação propriamente de crise, na qual a poesia será entendida como realização critica." (SISCAR, 2010, p. 75).

Siscar parte da ideia de profanação, presente em Deguy e Agambem para transformar o que é usado como mistificação histórica na chave de compreensão da própria história. Assim, de Baudelaire a Augusto de Campos, a poesia se define a partir do seu estado de crise, na crise se afirma o modo de ser da poesia na modernidade, que não cessa de "dramatizar" a crise.

Procurando escapar do determinismo marxista, mas sem recusar o recurso aos diagnósticos de época, Siscar vê o sacerdócio poético, a partir da ideia de profanação que desloca a dimensão do sacrifício do plano divino para o plano humano, como um martírio provocado pela violência das relações culturais. Assim, o sacrifício dos poetas e da poesia é na verdade "revelação do seu modo de ser no mundo contemporâneo" (SISCAR, 2010, p. 48).

Há evidentemente uma dimensão crítica em qualquer crise, mas reduzir a crítica há um estado perpétuo de crise não reduziria justamente as possibilidades e a amplitude crítica da crise? Uma crise que não tem fim pode ainda ser chamada de crise?

$\mathrm{Na}$ crise, segundo Siscar, a literatura procura formular uma "perspectiva própria ("autônoma") sobre o real". Mas, como isso seria possível se a crise não passa de uma mistificação histórica? Quer dizer, como pensar que a literatura pode ter uma perspectiva autônoma do real se, na verdade, a ideia de crise é fruto da própria ideologia burguesa? Inverter o diagnóstico de época, fazendo da ideologia a própria definição do literário transforma a literatura num instrumento, num produto da própria ideologia e, no interior desta perspectiva, a literatura é vitimizada, em todos os sentidos, principalmente, porque ela só pode se definir negativamente, como aquilo "que falta".

A crítica de Siscar diferentemente da de Schwarz não pode ser definida como uma crítica do desvelamento, já que transforma a própria mistificação no elemento chave para a compreensão do momento histórico. Assim, não desmistifica, mas sim contribui com o processo de mistificação, no caso, de martirização da poesia. Siscar não possui com relação ao texto literário a mesma distancia omnisciente de Schwarz. E esta proximidade entre o crítico e a obra impede que a ironia da poesia baudelairiana se mostre como a evidência maior da impossibilidade de toda e qualquer crítica no interior desta crise, chamada modernidade. A ironização baudelairiana de todos os valores românticos transforma o poeta num hipócrita, mascarado e escondido por trás desses ideais que se transformam em pura retórica. Este é justamente o maior sinal de falência da crítica, a constatação de que os ideais que até então moviam a poesia não são mais suficientes ou convincentes.

Siscar busca, na constatação da crise, a afirmação de sua força crítica. Mas, ele não entende esse processo como uma ironização, como cinismo, ou hipocrisia, ou má-fé, mas como uma simples dramatização. Segundo Siscar, a poesia de Baudelaire encontra sua dimensão crítica na medida em que o poeta dramatiza a crise da poesia e se mostra como um mártir. Mas, encenar a crise quando ela de outro, não é também uma forma de deboche, aliás, extravagante, como apenas um dandy seria capaz? Dramatizar não é também, como num placo de teatro, procurar maneiras, formas de dizer, estar, existir? Não é para ser outro que o ator se torna tal?

Esta definição de crítica é muito diferente da que está em operação no modo de racionalização do material musical, como mostra Safatle, em Cinismo e falência da crítica. Para o autor, o modo de racionalização cínica em operação nas sociedades do capitalismo avançado coloca em evidência a falência de um modelo critico baseado no desvelamento dos processos de racionalização social, ou na crítica da ideologia. E fornece inclusive um modelo de racionalidade do material musical, onde as formas mais gastas do sistema tonal são utilizadas para criticar o dodecafonismo, ou seja, como se o passado retornasse para destronar o novo. Não seria essa a força da ironia ou da dramatização da poesia de Baudelaire, nos guiar em direção ao novo?

Esta crise, que Siscar define como a essência mesma da modernidade, é também uma crise que atinge a crítica literária. Para De Man, esta urgência se manifesta nos anos 60 e 70 do nosso século, em que o estruturalismo, ao unificar as ciências humanas, criou uma competição em que cada dessas ciências, cada uma a sua maneira, buscava expor sua relevância e preponderância na determinação de um modelo metodológico para todo o campo das humanidades.

Esta urgência aparece como uma necessidade de legitimação da autonomização da arte que se paga nas ciências humanas com a sua unificação. Movimento interessante em que a linguagem, o estudo linguístico e a literatura autônoma fornecem para as ciências humanas 
o seu método. Mas, este imperativo de urgência que a crítica parece sentir pesar sobre ela, não se restringe a estas décadas do século XX, ela diz respeito a um período histórico muito mais amplo, a modernidade. Pois como vimos, a modernidade se define a partir do momento presente, na urgência do presente, que busca em si mesmo sua autocertificação.

Mas, existe uma nítida diferença entre uma ideia de crise e falência da crítica, que se demonstra através do esgotamento de uma determinada forma de crítica, e a ideia de crise presente em Siscar, como dramatização, que parece, na verdade, ser utilizada para justificar: 1 . O fato de que a crítica literária brasileira quando não repete a urgência de um "projeto nacional" se reduz à paráfrase. 2. Justificar a grande quantidade de poesia "média" no Brasil.

Nas últimas décadas, grande parte da crítica brasileira parece ter buscado refúgio na poesia "contemporânea", procurando encontrar uma alternativa ao modelo de crítica marxista, baseado na crítica da ideologia, no modelo de crítica como desvelamento, que procura encontrar na obra o contexto social que a produziu resultando assim num conhecimento sociológico sobre o Brasil, mas silenciando sobre a natureza do fato literário e sua especificidade.

Se a crítica procura encontrar refúgio na poesia contemporânea, a poesia do pós-tudo, posterior, portanto, à vanguarda concretista, é talvez porque reconheça nela algo que essa crítica procurava encontrar, uma alternativa à urgência de definição de uma literatura nacional e de um pensamento crítico eminentemente nacional, que marcou nossa literatura do romantismo ao concretismo. Com a poesia dos anos 70 e posterior, já não era preciso falar em construção da identidade nacional, já não era preciso pensar uma ideia de país que foi construída através dos mitos literários de José de Alencar a Guimarães Rosa. A crítica também não se preocupava em desmistificar esses mitos, apenas resolveu silenciar sobre o passado, buscando refúgio no presente. Por que não reconhecer o fim da urgência no estabelecimento de um modelo de literatura nacional? Por que não demonstrar o caráter mítico e mistificador de um projeto de criação de uma literatura nacional que se aliava aos ideais burgueses mais europeus?

Esta crítica contemporânea tem em comum com a poesia que lhe serve de objeto a ausência de um "projeto comum" (SIMON, 2010), ou melhor dizendo, o silêncio, sob seus verdadeiros interesses, silêncio crítico em relação ao passado que talvez seja o maior indício do estado de crise crítico que vivemos, pois sinaliza a impotência da crítica e da poesia, para se impor e se justificar em relação ao passado.

Se a poesia contemporânea tem dificuldade de se situar com relação ao passado, esta dificuldade é também presente na crítica, que volteia em torno da poesia procurando encontrar o seu verdadeiro caminho, incapaz de simplesmente julgar, de distinguir e diferenciar o que é bom do que não está simplesmente à altura (confuso...a altura de que?). Incapaz de dizer à a que veio. Neste caso, mesmo que Iumina ? detecte os problemas da poesia na sociedade brasileira ou nos novos (substituir a palavra paradigma por outra...) fornecidos pelo mundo globalizado, diagnóstico que nos parece insuficiente, o valor de sua crítica esta justamente na coragem de dizer o que a crítica deve dizer, julgar, decidir sobre o valor das obras. E na ideia de que crítica e poesia podem pensar juntas. Na ideia de que a crítica pode e deve colocar questões que a poesia deve ser capaz de responder.

Mas e se tomarmos esta liberdade com em relação ao cânone, que parece marcar a poesia contemporânea, como uma recusa de um parâmetro crítico, aquele justamente no qual Iumina se apoia, que entende que o papel do crítico diz respeito à "verificação crítica da tradição"? E se entendermos o modo como a poesia mais recente lida com o cânone como uma reinvenção?

A poesia sempre elege no cânone seus poetas de predileção e atualiza o cânone quando resgata elementos de um certo autor que convém ao estatuto atual da poesia. É o que aconteceu com Rimbaud e Lautréamont, por exemplo, no surrealismo. Ou o que ocorreu com Mallarmé, seja no concretismo, seja na leitura que o estruturalismo promoveu do autor. Assim, a poesia faz mais do que simplesmente verificar a pertinência de um autor na construção de uma literatura eminentemente nacional, ela vai além de verificar até que ponto a ficção corresponde a um estado histórico, ela promove uma reinvenção, uma releitura, uma reatualizarão crítica do cânone.

Antônio Cândido publicou Formação da literatura brasileira, no final dos anos 50. Esta obra é contemporânea do concretismo, o que quer dizer que a autonomização da literatura brasileira (que chegou com um século de atraso) se pagou na crítica com a "sociologização" da literatura. No momento em que a crítica francesa passa a desmistificar os ideais românticos que construíram sua literatura e o Estado francês contemporâneo, Estado burguês contemporâneo, a crítica brasileira busca compensar nosso retrocesso, reforçando os mitos do estado nacional, da identidade nacional e cultural. Mitos que a Europa, que conhecera em décadas anteriores o fascismo e o nazismo, não estava mais, de maneira nenhuma, disposta a alimentar.

Um movimento análogo ocorre na França em que a autonomização da arte fornece um modelo para a unificação de todo o campo das ciências humanas, que se inspira do modelo saussuriano da linguagem para criar um método comum. Mas, esta unificação das ciências 
humanas, na França, ao contrário do processo ocorrido no Brasil, se fez a partir da assunção do caráter autônomo da arte e não a partir de sua negação. Isso porque aqui, os ideais românticos que construíram nossa literatura, quando foram negados por esta, se transplantaram para a nossa crítica, que parecia padecer do mesmo desejo de modernização que movia o idealismo alemão. ${ }^{1}$

É o que transparece ao analisarmos o projeto crítico de Cândido, contido na ideia de Formação, a Bildung do idealismo alemão. Desde Schiller, o idealismo alemão é movido pelo desejo de construção de um "Estado de razão", não através da violência como foi o caso da revolução francesa, mas buscando construir uma moral capaz de criar e, sobretudo, de sustentar um Estado. Esta moral deveria ser buscada a partir da Estética. É assim que a arte se tornava responsável por um projeto político nacional. Com Madame de Staël, na França pósrevolucionária, o projeto se repete, tratava-se de fundar uma literatura nacional, de abandonar o neoclassicismo e a imitação dos modelos gregos em nome de uma arte que espelhasse a verdadeira configuração da sociedade e contribuísse para a fundação de uma República. Madame de Staël buscava assim, nos ideais da cavalaria, nos mitos medievais e na literatura provençal, ideais capazes de fornecer ao presente uma moral e costumes capazes de criar e manter um estado Republicano.

Wagner é assim um caso exemplar do romantismo e seu sucesso na França demonstra a semelhança entre os dois projetos político-estéticos, do romantismo francês e alemão, o músico também buscou nos mitos elementos para a definição de um Estado germânico, de uma cultura genuinamente germânica, mitos que seriam capazes de unificar e sustentar um estado nacional. Como José de Alencar, Mário de Andrade, Guimarães Rosa e tantos outros buscaram identificar e criar os mitos de uma nação "genuinamente" brasileira.

Na França, a reforma romântica começou no teatro, a arte mais claramente afinada com o antigo regime francês, pois seguindo os modelos representativos do teatro grego, divido em tragédia e comédia, gênero alto e baixo, o teatro clássico parecia perfeitamente adequado a uma sociedade estratificada e hierarquizada. Como mostra Szondi, em Origem do drama moderno, o surgimento do drama se deve ao desejo do meio liberal de construir uma arte que espelhasse a atual situação do mundo contemporâneo. Assim não era o burguês que precisava da tragédia, mas a tragédia que precisava do burguês para se modernizar. Madame de Staël, desde o começo do século; Stendhal em Racine e Shakespeare vão defender a ideia de um teatro adequado com a nova configuração social francesa.

\footnotetext{
1 Ver: ARANTES, Paulo. Ressentimento da dialética. Rio de Janeiro: Paz e Terra, 1996.
}

Mas a ideia de uma arte que correspondesse e espelhasse a sociedade que a produzia não nasceu no meio liberal francês, mas sim no meio conservador. Foi Bonald quem primeiro utilizou esta tese erigindo a reciprocidade entre arte e sociedade como princípio explicativo da História da arte que oscila entre momentos de progresso e de decadência, da qual padecia o século XVIII.

Assim, o autor defendia a restauração dos valores católicos e monarquistas contra a corrupção dos valores promovida pelos revolucionários do Século XVIII. Eis a prova de que a tese da dependência e correlação entre literatura e sociedade, que é essencialmente normativa e descritiva, pode servir tanto aos interesses "restauradores e conservadores" quanto aos ideais "progressistas".

A literatura moderna surge justamente reivindicando a autonomia e independência da arte com relação as outras esferas sociais. A modernidade é fruto do spleen baudelairiano que indica a falência do projeto de construção de um estado nacional a partir da literatura. O spleen é o sentimento provocado por um choque de realidade, ele é o sentimento que o poeta experimenta em L'implacable vie, quando a vida bate a porta do poeta e interrompe seus devaneios, seus sonhos. Spleen é a constatação do que é de fato o real, e da distância que o separa dos ideais poéticos românticos, dos ideais políticos que moveram a revolução e continuaram se propagando ao longo do século XIX, provocando a cisão entre a burguesia e o proletariado, provocando a revisão dos conceitos de liberdade e igualdade que teriam movido a revolução, mas que teimavam em permanecer restritos ao plano das ideias. Spleen é o sentimento provocado pela desilusão, pela constatação da falência destes ideais românticos, que procurava unir literatura e política, colocando aquela a serviço desta. Ela demonstra que o verdadeiro ato político consiste na negação da realidade sociedade partilhada, na renúncia da literatura em se deixar limitar e restringir ao que "ideólogos políticos" entendem por realidade.

Assim é preciso reconhecer que a literatura na modernidade não cessa de afirmar que a correspondência entre a literatura e a História, entre a ficção e o real, entre a literatura e a sociedade não é suficiente para legitimar e manter um Estado "democrático", ou construir o que se entende por "nação". Esta é a verdadeira experiência que a arte do fim da arte hegeliana parece querer evidenciar. Pois se a arte se desenvolve ao longo da História, se ela é eminentemente histórica, a estética hegeliana permite a eterna reversibilidade da relação literatura e sociedade, ou seja, se a arte fornece o espelho de uma época ela é também evidentemente capaz de criar e unir uma comunidade em torno de ideais e crenças comuns, exatamente como cabe à religião.

Mas a arte do fim da arte para Hegel é a arte que vai além do romantismo, que se desvincula totalmente 
da religião que, portanto, não tem mais a função de criar e unir uma comunidade. Por isso, devemos reconhecer que a literatura, a arte em geral, não é suficiente para legitimar, manter, criar ou sustentar um Estado livre, igualitário e fraterno. Pois se mesmo um conservador, monarquista e cristão como Bonald pode defender a ideia de uma literatura que forneça a sociedade seu espelho (mesma ideia de literatura que mobilizava o partido liberal francês), esta talvez seja a maior prova de que a literatura, se quiser, de fato, construir algo novo, para além de suas formas tradicionais deve também se libertar dos paradigmas que a limitam a mimeses e cópia do real. E é isto que entende Hegel por uma arte, uma literatura, no caso, do fim da arte, que se liberta da religião e assim se aproxima da filosofia na tarefa de fornecer à modernidade muito mais que o seu espelho, mas a sua reflexão, a sua verdade posta e exposta em conceitos.

Apesar dessas contradições e diferenças entre estes dois modelos críticos - o estruturalismo e o marxismo brasileiro - o fim do estruturalismo francês provocou, na França, um movimento análogo ao ocorrido na crítica brasileira das décadas recentes. Houve na França um retorno à crítica, digamos tradicional, representada pela Sorbonne, a crítica histórica, ou a história da literatura (neste período abundam os manuais generalizadores do tipo Romantismo, Simbolismo, Literatura do século XIX etc.) e houve também um retorno à crítica temática, anterior à reviravolta estruturalista. Um retorno à tradição, marcado por uma onda de excessiva moderação que parecia querer se desvincular dos excessos vanguardistas (Tel Quel) e acabava fazendo tábula rasa de todas as conquistas e questões que marcaram as décadas precedentes. Já no Brasil, o conservadorismo parece querer escapar dos imperativos políticos de urgência, sobretudo da ditadura do realismo que esta criou, refugiando-se na poesia contemporânea, já restrita a cenas cotidianas e a questões de "ordem menor". Aqui, a urgência política gerada pela ditadura militar, diante da qual o marxismo talvez fosse a única alternativa moralmente aceitável e inclusive uma demonstração de responsabilidade intelectual admirável, acabou gerando na crítica literária uma outra ditadura, a do realismo. Muita afinada inclusive com as diretrizes stalinistas a respeito da arte comunista que encontrou em Lukàcs seu maior representante.

Esta crítica criou uma ditadura do realismo e do romance como gênero maior relegando a poesia a um espaço subalterno na literatura nacional. O que explica e reforça a ideia da falência do modelo de crítica marxista brasileiro e seus "ideais românticos" é a enorme quantidade de poetas que apareceram na cena cultural desde os anos 50, sem falar da efervescência na música popular do período. Poetas para os quais esta crítica parece não dispor de parâmetros de julgamento distintos dos utilizados para os autores do romantismo (leia-se de José de Alencar até Guimarães Rosa, chegando inclusive aos romances regionalistas mais recentes). Ou seja, o fato de esta crítica não reconhecer a qualidade de nenhum autor posterior à década de 50 , também coloca em evidência a falência de seus parâmetros críticos frente à produção literária mais recente.

$\mathrm{Na}$ crítica brasileira, leia-se Roberto Schwarz, este regime de urgência teria provocado, segundo Siscar, uma transformação, uma passagem de um regime discursivo da interpretação a um regime do fato histórico, "entendido como um discurso do fato, do dado especulativo objetivo, o discurso da história pressupõe o conteúdo histórico como presença plena à disposição do relato ou da narração." (SISCAR, 2010, p. 205). Como Prado Jr., Siscar crítica a unilateralidade do discurso crítico marxista, que reduz todas as possibilidades interpretativas a uma via de mão única. E silencia sobre o fato literário em si mesmo. Já na França, os paradigmas interpretativos parecem ter sido reforçados após os excessos vanguardistas, produzindo uma crítica inteiramente dedicada ao comentário, ou a paráfrase. Tanto num caso quanto no outro, a crítica parece em crise por insistir em repetir e afirmar um estado de coisas que ela não parece capaz de ultrapassar. Ela parece incapaz de pensar para além da configuração histórica, para além do próprio texto literário, claramente afirmar seu desejo de transformação, seu desejo de ir além de um estado de crise.

Assim, o que nos permite comparar a nossa situação atual, seja no Brasil, seja na França, marcada por um marasmo pós-vanguardista, ou por uma pluralidade de vozes idênticas na ausência de força, com a situação da poesia francesa em meados do século XIX é que, tanto ontem, no nascimento da modernidade, quanto hoje, onde ela parece ter alcançado seu fim, o diagnóstico é o mesmo: estamos diante de momentos em que se pode constatar a falência de paradigmas críticos.

A poesia brasileira parece que há apenas pouco tempo superou os paradigmas da arte romântica. E esta constatação parece que chega apenas agora a se manifestar na crítica, mesmo que de maneira ainda tímida. O mesmo ocorria na França, nos anos de crise da crítica ou de efervescência da vanguarda, pois como afirmava Foucault (1996, p. 221), o estruturalismo não era "um método novo, ele é a consciência desperta e inquieta do saber moderno".

Assim, estamos diante de dois momentos muito próximos, o nascimento da modernidade e o momento em que ela aparece revelada e consciente de si mesma no estruturalismo, dois momentos de crise que indicam, na verdade, dois começos, momentos em que a renovação de paradigmas críticos aparece como a questão a ser pensada. 
Este diagnóstico foucaultiano é muito diferente do diagnóstico de falência da crítica que Safatle demonstra através da racionalidade cínica, pois para Foucault, o estruturalismo reconhece a necessidade de autocertificação da modernidade como consequência da autonomização das esferas do saber e encontra na linguagem o espelho para demonstrar o funcionamento desta operação de autocertificação. Mostrando que a linguagem autônoma pode dizer tudo, mas a partir do seu próprio funcionamento, de sua própria aparência, no seu ser. Já o cinismo indica o fim da crítica como desvelamento, o esgotamento da crítica marxista como crítica da ideologia, o que talvez implique um retorno a Marx, não o jovem, mas o segundo que teria como mostra Foucault ao lado de Freud e Nietzsche e acrescentamos também Mallarmé, realizado uma crítica da representação. O que a racionalidade cínica demonstraria, se a pensássemos no interior dos mecanismos representativos é a impossibilidade de abandono total da representação, que torna inclusive possível uma espécie de crítica mimética teorizada por Adorno.

\section{Mallarmé, a crise e o acaso}

É curioso que Mallarmé, um poeta reconhecidamente "obscuro" possa nos servir neste caso como paradigma de clareza crítica. Pois, se a poesia mallarmena pode nos indicar um caminho para a saída do estado de crise ela se encontra justamente, como De Man sugere, na necessidade de ir ao fundo das coisas, as origens e causas da crise que só podem ser evidenciadas quando nos questionamos sobre a natureza do próprio fato literário.

Se observarmos os estudos mais recentes sobre Mallarmé, as teses escritas nos últimos anos na França, vemos que há um interesse cada vez maior pelo Mallarmé dos "versos de circunstância", na tentativa de se encontrar talvez, um "antecessor" da nossa poesia contemporânea, tão voltada para o cotidiano. O que é muito interessante, pois esta talvez seja a maneira mais profícua de lermos os grandes autores da tradição, perguntando-lhes o que sua obra teria a dizer sobre as questões que estão na ordem do dia da contemporaneidade. E a poesia de Mallarmé se presta muito bem a esse exercício.

Penso que grande parte da poesia de Mallarmé guarda algo de seus "versos de circunstância", a leveza, preferiria dizer o Tom. No entanto, o que diferencia os versos de circunstância da "poesia em si" é o peso que esta carrega, a profundidade, o caráter "essencial" não necessariamente do tema, mas da relação que este estabelece com a forma.

Mesmo sendo leve, a poesia mallarmeana não é casual ou gratuita como grande parte de poesia contemporânea. Este equilíbrio, entre o leve e o pesado e denso não é apenas uma característica irredutível das relações amorosas, mas a obra de um grande poeta, único capaz de ancorar um navio no espaço.

Por isso, diante da urgência do presente, ou como diria Mallarmé, diante da sua inexistência ("algo como o presente, não existe") talvez devêssemos nos colocar as questões também mais urgentes, talvez devêssemos levar a sério a crítica mallarmeana a Wagner e nos dirigirmos "à fonte", à origem do problema.

Se a literatura não tem lugar na praça pública e parece irrelevante no interior da vida social porque insiste em se manter fora da indústria cultural, então devemos admitir o óbvio: escrever não é preciso. Mallarmé estava tão certo disto que chegou inclusive a se perguntar se "algo como as letras existe". Esta questão é fundamental, pois se estivermos dispostos a aceitar a resposta "exagerada" do poeta, como ele mesmo reconhece: "Sim, que a literatura existe e, se quisermos, só, com a exclusão de tudo. Realização, ao menos, para qual não cabe melhor nome." (MALLARMÉ, 2003, p. 66), seria preciso encontrar na literatura as razões pelas quais ela se impõe como uma necessidade.

Assim, é preciso ir além da afirmação da crise, da constatação de um estado de crise. A crítica de Siscar nos faz pensar no diagnóstico da modernidade feito por Nietzsche. Para o filósofo que se dispôs a pensar algo além do homem, algo como o super-homem a situação de crise, de decadência da arte moderna era insuportável. Para Nietzsche, Wagner é um artista doente, um artista decadente para tempos igualmente decadentes. Segundo o filósofo nenhum outro como Wagner soube expor o que há de melhor e de pior na modernidade, na sua boca a modernidade fala a sua língua mais intima, perde inclusive todo seu pudor. Wagner soube oferecer aos modernos tudo o que mais necessitam: o brutal, o artifício e a ingenuidade. Segundo Nietzsche, ele não passava de um neurótico que tinha a pretensão de salvar o homem moderno através da música, assumindo um papel que outrora pertenceu à religião.

Nietzsche destaca a intimidade entre Wagner e o romantismo francês, "os maiores representantes da cultura literária mundial", artistas que combinam os sentidos e as artes, "fanáticos da expressão", grandes no campo dos efeitos, da encenação, virtuosos e com talento, mas não gênios, inimigos da lógica e defensores do exótico, enfim, artistas doentes. Entre as características da arte decadente estão, segundo Nietzsche, o ocaso da força organizadora, o abuso dos meios tradicionais, sem justificativa, sem um fim; a cunhagem de falsa moeda na imitação das grandes formas diante das quais nada é forte e firme o bastante; a excessiva vitalidade dos detalhes; a paixão a todo custo; o refinamento como expressão da vida empobrecida; enfim 
"sempre os nervos no lugar da carne". Para Nietzsche, a arte moderna é decadente porque parece ter perdido não apenas seu vínculo essencial com a vida, mas, sobretudo sua substância, sua força organizadora. Ao diagnosticar o problema da arte como uma enfermidade, Nietzsche transforma a crise da modernidade numa simples quimera, no produto da neurose de artistas com pouco talento. Assim, é preciso que arte, deixe de querer ser um meio de garantir redenção para neuróticos de nervos enfraquecidos, é preciso que ela se torne um fim em si mesma.

Assim, a arte não admite meias verdades, meia vontade, meias palavras. Ela deve ser absoluta. Isto significa que se a literatura existe e ninguém estaria dispostos a duvidar, então devemos admitir que há algo de fundamental na operação que ela realiza para poder existir, a operação pela qual ela exclui tudo o que lhe é exterior. Pois se a literatura existe só "com a exclusão de tudo" é porque há algo de fundamental na literatura, de absolutamente essencial que permite que ela exista, sem precisar de nenhum apoio exterior sob o qual se sustentar. Diante desta constatação, a questão que devemos nos colocar é a seguinte: "O que é de fato a literatura, e porque ela nos parece tão fundamental?"

De Man tem uma resposta para essa pergunta. Para o autor, na literatura, signo e significado nunca coincidem, é isto que define a linguagem que chamamos literária, a única que pode escapar da falência de uma expressão não mediada. Todos sabemos disso, no entanto, desejamos que isto não seja verdade. Mas a verdade emerge quando pensamos a literatura de acordo com sua verdadeira natureza, ou seja, como ficção. A separação entre a literatura e o mundo empírico, a sua diferença com relação ao significado, que depende para existir da atividade constitutiva do próprio signo, é o que caracteriza a literatura. Por isso, a literatura não é um mito e não funciona como tal, ela se sabe e se nomeia ficção, ela é, a princípio, desmistificada, ela nos fala de um lugar privilegiado em que se trata de nomear: a presença do Nada. Exatamente como no caso de Mallarmé. O que caracteriza a literatura, segundo De Man é justamente sua insistência em evocar e nomear "o nada" que caracteriza a existência humana.

Assim, de Man empreende como Prado Jr. e como Safatle, uma crítica ao modelo de crítica marxista e estruturalista que se vê como uma crítica do desvelamento. De Man nos mostra o que há de mais evidente na arte: seu caráter ficcional; e nos remete mais uma vez à crítica mallarmeana e nietzscheana a Wagner, onde era questão de mostrar que a verdadeira obra de arte não cria mitos, ela é em si mesmo crítica, pois desvela a natureza dos mitos, os ironiza, os dissolve; assim, eles aparecem como mitos simplesmente, ficções.
A verdadeira obra de arte, as grandes obras de arte românticas e modernas realizam sozinhas, no seu interior, o seu papel crítico, elas não requerem o crítico para explicá-la ou interpretá-la. A verdadeira obra de arte se constitui a partir da consciência de seu caráter ficcional, a partir da consciência do seu caráter representativo, ou seja, demonstrando e problematizando, a distância que separa a linguagem do mundo que ela procura conhecer ou criar.

No que diz respeito a esta afirmação de De Man, de que a arte repete sempre a mesma afirmação, evidenciando o Nada que caracteriza a existência humana, Mallarmé diria que, de fato, o Nada parece ser mesmo o único nome capaz de conter em si mesmo a totalidade da existência humana. No entanto, a literatura não é apenas uma tentativa de nomear este vazio, porque o Nada de Mallarmé não é um vazio, ele é um começo. Ele coloca em evidência, como De Man ressalta, que na literatura signo e significado não coincidem, que o mundo empírico é um outro, que a literatura deseja e repele ao mesmo tempo. Mas, isso significa dizer que a literatura, enquanto ficção, tem um estatuto privilegiado com relação ao "mundo empírico" e ao "mundo do significado".

A literatura é assim uma espécie de arte do equilibrista. Enquanto ficção, como o outro do real, a literatura é mera possibilidade, mas toda possibilidade, por mais improvável que seja sempre pode se tornar algo mais que uma possibilidade, sempre pode se tornar real. Assim, a literatura existe procurando se equilibrar entre dois mundos, desejando que eles possam ser apenas um. Desta maneira, devemos sempre compreender a literatura a partir da seguinte pergunta: "O que a literatura nos ensina sobre uma realidade que parece sempre evidente, pois é socialmente partilhada?" Não é a literatura e o pensamento filosófico aquilo que está fora do sensocomum? A literatura não é apenas uma possibilidade que pode se tornar real, ela nos mostra, sobretudo, que o real é apenas uma questão de interpretação, por isso o acaso, aparece como categoria determinante na reestruturação da literatura para Mallarmé. Pois ele determina um outro modo de relação com o real, ele pressupõe não mais a certeza, mas a dúvida, abrindo espaço para a interpretação. Como tudo o que é por excelência indeterminado, o real, este que é feito de acaso, é sempre algo a ser descoberto, algo que está por vir, algo que deve ser escrito.

O encontro mallarmeano com o Nada não se resume, portanto, a uma simples espiadela no abismo que separaria o signo de sua referência e de seu significado, ela indica uma experiência fundamental, sob o que de fato significa escrever. Escrever significa, irremediavelmente, quando se procura ir até a origem deste ato, até o fundo do abismo, 
deparar-se com o Nada. O que Mallarmé parece sugerir com a sua crise é que talvez se admitirmos finalmente que não há nada para ser dito, se admitirmos a natureza mesma da ficção, possamos começar a pensar em dizer alguma coisa, pois, é do Nada que surge o Verbo, e é no acaso que a poesia encontra sua fonte. $\mathrm{O}$ acaso é aqui a figura maior deste Nada que não é um simples vazio, ou um vazio absoluto, mais a ausência de causa ou razão. $\mathrm{O}$ acaso é o meio pelo qual podemos nos liberar da urgência do presente, da gramática desgastada do passado, fazendo tábula rasa dos ideais românticos, mas evidentemente não de toda tradição, deixando para trás a crise, deixando para trás o monstro da impotência. O que a poesia mallarmeana sugere, a partir do seu encontro com o Nada, é que se nós formos capazes de nos liberarmos das evidências do presente, das prerrogativas urgentes e de seus imperativos factuais, da gramática desgastada dos ideais absolutos e da necessidade de expressão, se deixarmos definitivamente o passado para trás e confiarmos na sutileza dos gestos mínimos do acaso, talvez possamos encontrar, na sua leveza, um caminho para a reconfiguração da sintaxe que nos permitirá, quem sabe, abrir pequenas frestas na máquina do mundo.

\section{Referências}

DE MAN, Paul. Criticism and crisis. Blindness and insight: essays in the rhetoric of contemporary criticism. London: Routledge, 1989.

FOUCAULT, Michel. Nietzsche, Freud e Marx. São Paulo: Princípio, 1997.

FOUCAULT, Michel. Les mots et les choses. Paris: Gallimard, 1996.

MALLARMÉ, Stéphane. Euvres complètes. Paris, Gallimard, 2003.

PRADO JUNIOR, Bento. Alguns ensaios: filosofia, literatura, psicanálise. São Paulo: Paz e Terra, 2000.

SAFATLE, Vladimir. Cinismo e falência da crítica. São Paulo: Boitempo, 2008.

SISCAR, Marcos. Poesia e crise. São Paulo: Editora da Unicamp, 2008.

SIMON, Iumina. O que fizeram com a poesia brasileira. Piauí, Rio de Janeiro, n. 61. Outubro, 2010. Disponível em: <http:// www.revistapiaui.com/edicao-61/aceleracao-do-crescimento/ condenados-a-tradicao>. Acesso em: 26 nov. 2010.

Recebido: 10 de fevereiro de 2015

Aprovado: 14 de agosto de 2015

Contato: larissa_drigo@yahoo.com.br 